\title{
BUDIDAYA DAN PEMANFAATAN TANAMAN YACON (Smallanthus sonchifolius) UNTUK MENINGKATKAN POTENSI ALAM DAN PEMBERDAYAAN MASYARAKAT DESA ARGOSARI, KECAMATAN SENDURO, KABUPATEN LUMAJANG
}

\author{
Oleh: \\ Dhita Ayu Permata Sari ${ }^{5}$

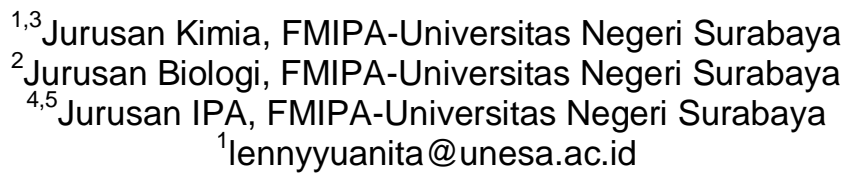

Leny Yuanita ${ }^{1}$, Rinie Pratiwi Puspitawati ${ }^{2}$, Prima Retno Wikandari ${ }^{3}$, Wahyu Budi Sabtiawan ${ }^{4}$,

\begin{abstract}
Abstrak
Target utama yang diharapkan melalui kegiatan Program KKN-PPM meliputi dua hal yaitu 1) memberdayakan masyarakat dan mengembangkan potensi alam, 2) memberi keterampilan mahasiswa keterampilan bersosialisasi dan memecahkan masalah di masyarakat. Luaran utama dari kegiatan ini adalah kesejahteraan masyarakat yang meningkat melalui budidaya dan pemanfaatan tanaman yacon di desa Argosari, Kecamatan Senduro, Kabupaten Lumajang. Kegiatan KKN-PPM dilakukan selama 3 bulan dimulai pada bulan April sampai dengan Juli 2016. Namun untuk pelaksanaan evaluasi hasil budidaya tetap dilakukan sampai panen umbi yacon (sekitar 8 bulan). Hasil kegiatan: Yacon merupakan tanaman yang sesuai untuk ditanam di Desa Argosari Kecamatan Senduro Kabupaten Lumajang Jawa Timur. Tanaman tersebut telah berhasil ditanam dan diolah menjadi teh yacon oleh petani di desa tersebut. Mahasiswa KKN telah mampu bersosialisasi dengan masyarakat Desa Argosari melalui program penanaman yacon. Mahasiswa juga menunjukkan sikap tanggung jawab yang dapat dilihat dari perawatan tanaman yacon selama kegiatan KKN. Mahasiswa telah mampu mengembangkan keterampilan mereka, khususnya dalam hal bercocok tanam yacon. Kegiatan yang dilakukan mahasiswa selama KKN meliputi pelatihan penanaman yacon, penanaman bibit, dan perawatan tanaman yacon.
\end{abstract}

Kata Kunci: Budidaya dan pemanfaatan yacon, pemberdayaan masyarakat, Argosari

\begin{abstract}
The main targets are expected through KKN PPM program consists of two things: 1) empowering citizens and developing the natural potential, 2) give students skills and social skills to solve problems in the community. The primary outcome of this activity is community wellbeing through the cultivation and utilization of yacon plant in the village Argosari, Senduro, Lumajang. KKN PPM activities carried out for 3 months starting in April to July 2016. However, for the evaluation of the results of the cultivation is still being done to harvest the tubers yacon (approximately 8 months). Results of activity: Yacon is a plant that is suitable for planting in the Argosari, Senduro, Lumajang, East Java. The plant had been successfully grown and processed into tea yacon by farmers in the village. KKN students have been able to socialize with the village community through a program of planting yacon Argosari. Students also shows the attitude of responsibility that can be seen from the yacon plant care during learning activities. Students have been able to develop their skills, particularly in terms of planting yacon. Activities undertaken include training students for service learning yacon cultivation, planting, and maintenance yacon plant.
\end{abstract}

Keywords: Cultivation and use of yacon, empowering citizens, Argosari

\section{PENDAHULUAN}

Desa Argosari merupakan salah satu desa di Kecamatan Senduro yang terletak di Kabupaten Lumajang. Luas Wilayah Kecamatan Senduro keseluruhan adalah 228,67 km2. Ketinggian Wilayah di Desa Argosari Kecamatan Senduroberkisar antara 200 sampai dengan 2900 meter di atas permukaan laut, dan suhu minimum mampu mencapai dibawah $10^{\circ} \mathrm{C}$. Curah hujan di desa tersebut dapat dikatakan dalam kategori curah hujan tinggi (Pemkab Lumajang, 2015). Puncak B-29 di Desa Argosari berpotensi sebagai kawasan wisata yang menarik jika dikelola dengan baik.

Sebagian besar penduduk Desa Argosari Kecamatan Senduro sesuai potensi dan 
kondisi wilayah, hidup dari sektor pertanian sebagai petani dan buruh tani sayur, terutama kentang, sawi, kubis, dan bawang daun. Ada sebagian kecil berprofesi sebagai pegawai negeri sipil. Kondisi kesejahteraan penduduk berdasarkan pendapatan Rumah Tangga masih tergolong menengah ke bawah. Topografi Desa Argosari yang merupakan dataran tinggi dan pegunungan tentunya sulit mendukung pelaksanaan program pembangunan sesuai yang diinginkan, sebaliknya kondisi yang demikian memiliki keadaan tanah yang cukup subur dan tentunya dapat mendukung pembangunan dan laju kegiatan perekonomian melalui pertanian. Dengan pengelolaan sumber daya alam yang dilakukan secara efisien dan efektif akan mendorong upaya peningkatan kesejahteraan masyarakat.

Seperti yang dijelaskan pada RPJMD Kabupaten Lumajang Tahun 2015-2019, visi dari kabupaten tersebut adalah "Terwujudnya Masyarakat Lumajang yang Sejahtera dan Bermartabat" dengan salah satu misinya adalah "Meningkatkan Perekonomian Daerah dan Masyarakat Berbasis Pertanian". Selain visi dan misi, RPJMD tersebut juga mengungkapkan mengenai masalah yang dihadapi oleh Kabupaten Lumajang, antara lain belum optimalnya pertumbuhan sektor pertanian dan potensi hutan rakyat masih perlu dioptimalkan (Pemkab Lumajang, 2015). Dengan demikian, perlu adanya optimalisasi lahan pertanian di Kabupaten Lumajang khususnya Desa Argosari.

Tanaman yacon (Smallanthus sonchifolius (Poepp. \& Endl.) H. Robinson) baru dikenal di Indonesia sekitar tahun 2006, telah dibudidayakan di Wonosobo Jawa Tengah, dan belum terdapat di Jawa Timur. Tanaman ini memiliki nilai ekonomis tinggi dan merupakan tanaman umbi yang sangat mudah ditanam hanya dengan cara vegetatif dari rizomanya. Yacon tumbuh dengan baik pada habitat dengan ketinggian lebih dari 2000 meter di atas permukaan laut, walaupun dapat tumbuh pada ketinggian 1000 meter asalkan melalui irigasi yang teratur. Yacon dapat ditanam sepanjang tahun dan akan tumbuh sangat baik pada tanah yang kandungan bahan organiknya tinggi dan $\mathrm{pH}$ netral atau sedikit asam. Menurut Douglas et al. (2007), pertumbuhan optimal tercapai pada suhu antara $18-25^{\circ} \mathrm{C}$, walaupun dapat bertahan hingga $40{ }^{\circ} \mathrm{C}$ asalkan mendapat cukup air. Maka berdasarkan letak geografisnya, Desa Argosari, kecamatan
Senduro kabupaten Lumajang sangatlah tepat digunakan sebagai tempat budidaya tanaman yacon di Jawa Timur.

Umbi yacon bernilai ekonomis tinggi karena dapat digunakan sebagai pemanis alami, mempunyai aktivitas hipoglikemik dan hipokolesterolemik, serta meningkatkan absorpsi mineral (Yuanita dkk., 2013, 2014). Umbi yacon dapat dikonsumsi mentah dengan rasa manis segar, dan diolah menjadi kripik, selai, dan sirup. Menurut Manrique et al.,(2004), tiap 100 gram umbi yacon segar mengandung 6-12 gram prebiotik FOS (fruktooligosakarida) dan 1,5-4 gram gula (sukrosa, glukosa, fruktosa). Kandungan prebiotik FOS yang tinggi pada yacon berguna bagi pembentukan sinbiotik dan sangat menguntungkan bagi pencernaan dan kesehatan, khususnya menghambat bakteri patogen (Yuanita dkk., 2015). Daun yacon berperan dalam penurunan glukosa, kolesterol darah, antibakteri, dan fungisida (Lachman et al., 2003).

Berdasarkan analisis situasi di atas, maka tujuan kegiatan: 1) memberdayakan masyarakat, dalam mengembangkan potensi alam melalui budidaya dan pemanfaatan tanaman yacon, 2) mahasiswa KKN dapat mempunyai keterampilan bersosialisasi dengan masyarakat sehingga dapat membentuk sikap bertanggung jawab terhadap kemajuan masyarakat serta mempunyai keterampilan meningkatkan kesejahteraan masyarakat melalui pembudidayaan dan pemanfaatan yacon di Desa Argosari Kecamatan Senduro Kabupaten Lumajang. Target utama yang diharapkan melalui kegiatan Program KKNPPM meliputi dua hal yaitu 1) memberdayakan masyarakat dan mengembangkan potensi alam, 2) memberi keterampilan mahasiswa keterampilan bersosialisasi dan memecahkan masalah di masyarakat. Luaran utama dari kegiatan ini adalah kesejahteraan masyarakat yang meningkat melalui budidaya dan pemanfaatan tanaman yacon.

\section{METODE PELAKSANAAN}

Fokus utama dalam pelaksanaan KKNPPM ini adalah pemberdayaan masyarakat dan meningkatkan potensi alam di Desa Argosari melalui pembudidayaan tanaman yacon, sehingga melalui kegiatan ini mampu memfasilitasi masyarakat dalam rangka peningkatan kesejahteraan mereka. Adapun strategi yang akan dilakukan untuk mencapai 
tujuan atau fokus utama dalam kegiatan KKN-PPM ini disajikan pada Tabel 1.

Tabel 1. Strategi Penyelesaian Masalah

\begin{tabular}{|c|c|c|}
\hline Kegiatan & Target Sasaran & Tindak Lanjut \\
\hline $\begin{array}{l}\text { Pembekalan mahasiswa } \\
\text { KKN-PPM tentang kondisi } \\
\text { Desa Argosari, cara } \\
\text { bersosialisasi yang baik, } \\
\text { tugas-tugas mahasiswa } \\
\text { sebagai peserta KKN- } \\
\text { PPM, dan teknik } \\
\text { pembibitan dan } \\
\text { penanaman yacon }\end{array}$ & $\begin{array}{l}\text { - } \quad \text { Mahasiswa KKN } \\
\text { - Tim KKN-PPM }\end{array}$ & $\begin{array}{l}\text { Mahasiswa memahami cara } \\
\text { bermasyarakat atau } \\
\text { bersosialisasi yang baik dalam } \\
\text { masyarakat ketika berada di } \\
\text { tempat KKN-PPM. } \\
\text { - Mahasiswa memahami } \\
\text { tugasnya pada kegiatan KKN- } \\
\text { PPM. } \\
\text { Mahasiswa memahami cara } \\
\text { budidaya dan pemanfaatan } \\
\text { tanaman yacon. }\end{array}$ \\
\hline $\begin{array}{l}\text { Koordinasi dengan Aparat } \\
\text { Desa Argosari }\end{array}$ & $\begin{array}{ll}- & \text { Tim KKN-PPM } \\
\text { (Dosen, Mitra dan } \\
\text { Mahasiswa) } \\
\text { - } \quad \text { Kepala Desa dan } \\
\text { Perangkat Desa }\end{array}$ & 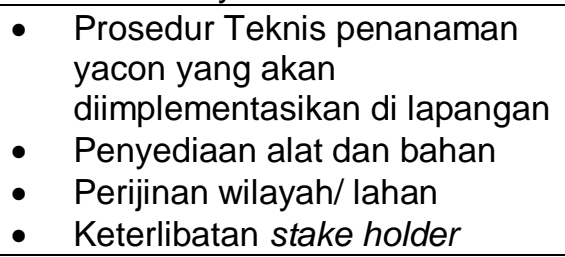 \\
\hline $\begin{array}{l}\text { Sosialisasi Program } \\
\text { Pembudidayaan yacon }\end{array}$ & $\begin{array}{ll}\text { - } & \text { Aparatur desa } \\
\text { meliputi Kepala Desa, } \\
\text { Perangkat Desa, dan } \\
\text { Tokoh Masyarakat } \\
\text { Masyarakat Desa } \\
\text { Argosari yang terpilih } \\
\text { sebagai pilot project } \\
\text { dan pemilik lahan. } \\
\end{array}$ & $\begin{array}{l}\text { Masyarakat memahami mengenai } \\
\text { program pembudidayaan yacon } \\
\text { yang akan diterapkan di } \\
\text { wilayahnya. }\end{array}$ \\
\hline $\begin{array}{l}\text { Pelatihan Penanaman } \\
\text { yacon }\end{array}$ & $\begin{array}{ll}- & \text { Tim KKN-PPM } \\
\text { (Dosen, Mitra, dan } \\
\text { Mahasiswa) } \\
\text { Masyarakat Desa } \\
\text { Argosari yang terpilih } \\
\text { sebagai pilot project } \\
\text { dan pemilik lahan. } \\
\end{array}$ & $\begin{array}{l}\text { Masyarakat memahami } \\
\text { mengenai cara budidaya } \\
\text { yacon. } \\
\text { Kepala Desa menginstruksikan } \\
\text { kepada warga yang terpilih } \\
\text { sebagai pilot project untuk } \\
\text { segera melakukan penanaman. }\end{array}$ \\
\hline Pelaksanaan Lapangan & $\begin{array}{ll}- & \text { Tim KKN-PPM } \\
\text { (Dosen, Mitra, dan } \\
\text { Mahasiswa) } \\
\text { Masyarakat Desa } \\
\text { Argosari yang terpilih } \\
\text { sebagai pilot project } \\
\text { dan pemilik lahan. }\end{array}$ & $\begin{array}{l}\text { Keterlibatan semua unsur } \\
\text { masyarakat yang berada di Desa } \\
\text { Argosari }\end{array}$ \\
\hline $\begin{array}{l}\text { Pendampingan, } \\
\text { Pengelolaan, dan } \\
\text { Perawatan }\end{array}$ & $\begin{array}{ll}\text { - } & \text { Tim KKN-PPM } \\
\text { (Dosen dan } \\
\text { Mahasiswa) } \\
\text { Masyarakat Desa } \\
\text { Argosari yang terpilih } \\
\text { sebagai pilot project } \\
\text { dan pemilik lahan }\end{array}$ & $\begin{array}{l}\text { Kebijakan Kepala Desa Argosari } \\
\text { mengenai Penanaman Tanaman } \\
\text { yacon sebagai Salah Satu Komoditi } \\
\text { di Desa Argosari }\end{array}$ \\
\hline $\begin{array}{l}\text { Pemanfaatan daun yacon } \\
\text { sebagai teh yacon }\end{array}$ & $\begin{array}{ll}\text { - } & \text { Tim KKN-PPM } \\
\text { (Dosen, Mitra, dan } \\
\text { Mahasiswa) } \\
\text { - } \text { Masyarakat Desa } \\
\text { Argosari yang terpilih } \\
\text { sebagai pilot project }\end{array}$ & $\begin{array}{l}\text { - Masyarakat dapat } \\
\text { memanfaatkan daun yacon } \\
\text { sebagai teh yacon } \\
\text { (mulai pemetikan hingga } \\
\text { pembuatan teh yacon) }\end{array}$ \\
\hline
\end{tabular}




\begin{tabular}{|c|c|c|}
\hline Kegiatan & Target Sasaran & Tindak Lanjut \\
\hline \multicolumn{3}{|c|}{ dan pemilik lahan. } \\
\hline $\begin{array}{l}\text { Evaluasi Hasil } \\
\text { Penanaman Yacon }\end{array}$ & $\begin{array}{l}\text { Tim KKN-PPM (Dosen } \\
\text { dan Mahasiswa) }\end{array}$ & $\begin{array}{l}\text { Validasi teknik dan hasil } \\
\text { penanaman yacon }\end{array}$ \\
\hline $\begin{array}{l}\text { Pengolahan Data Hasil } \\
\text { Kegiatan KKN-PPM }\end{array}$ & $\begin{array}{l}\text { Penyusunan Laporan } \\
\text { KKN-PPM }\end{array}$ & $\begin{array}{l}\text { Sosialisasi dan publikasi hasil } \\
\text { program pembudidayaan tanaman } \\
\text { yacon }\end{array}$ \\
\hline Publikasi & $\begin{array}{l}\text { Dokumentasi profil dan } \\
\text { hasil penerapan teknologi } \\
\text { penanaman yacon }\end{array}$ & $\begin{array}{l}\text { Program percontohan untuk dapat } \\
\text { diimplementasikan lebih lanjut, } \\
\text { pada sekitarnya }\end{array}$ \\
\hline
\end{tabular}

Teknologi yang akan diterapkan terdiri dari dua hal, yaitu: 1) teknologi budidaya yacon dan 2) teknologi pembuatan teh yacon. Teknologi budidaya tanaman yacon yang akan diterapkan di Desa Argosari meliputi penyemaian bibit, pengolahan media tanam, perawatan tanaman, dan panen-pascapanen. Setelah daun tanaman yacon siap dipanen, daun tersebut akan diolah menjadi produk teh yacon. Teknik pembuatan teh yacon meliputi proses pelayuan, pendinginan, penggulungan daun, dan pengeringan. Mekanisme kegiatan secara rinci mengikuti langkah seperti tertera pada Gambar 1.

\begin{tabular}{|c|c|c|}
\hline $\begin{array}{l}\text { PERSIAPAN KKN-PPM } \\
\text { Observasi lapangan, perijinan, } \\
\text { pembekalan mahasiswa, koordinasi } \\
\text { dengan mitra, pemilihan lokasi untuk }\end{array}$ & \multirow{2}{*}{$\begin{array}{l}\text { PELAKSANAAN KKN PPM: } \\
\text { Sosialisasi program, } \\
\text { Pengadaan, pemilihan, benih; } \\
\text { Penyemaian benih; } \\
\text { Penanaman; Pemeliharaan, } \\
\text { panen daun, pemanfaatan daun } \\
\text { dan umbi }\end{array}$} & $\begin{array}{l}\text { Laporan Hasil } \\
\text { Kegiatan KKN oleh } \\
\text { mahasiswa }\end{array}$ \\
\hline $\begin{array}{l}\text { perancangan teknologi pertanian; } \\
\text { Perencanaan KKNPPM }\end{array}$ & & \multirow{2}{*}{$\begin{array}{l}\text { EVALUASI: } \\
\text { - Analisis potensi } \\
\quad \text { alam } \\
\text { - Analisis masyarakat } \\
\text { - Analisis manfaat } \\
\text { - Evaluasi partisipasi } \\
\text { aktif }\end{array}$} \\
\hline $\begin{array}{l}\text { EVALUASI: } \\
\text { - Analisis potensi alam } \\
\text { - Analisis masyarakat } \\
\text { - Evaluasi partisipasi aktif } \\
\text { - Monitoring, evaluasi program }\end{array}$ & $\begin{array}{l}\text { EVALUASI: } \\
\text { - Monitoring- Evaluasi Program } \\
\text { - Evaluasi partisipasi aktif }\end{array}$ & \\
\hline
\end{tabular}

Gambar 1. Mekanisme Pelaksanaan Kegiatan KKN-PPM

\section{HASIL DAN PEMBAHASAN}

Kegiatan KKN-PPM yang telah dilaksanakan pada tanggal 4 Maret 2016 sampai tanggal 8 Agustus 2016 di Desa Argosari, Kecamatan Senduro, Kabupaten Lumajang. kegiatan yang telah dilaksanakan adalah sebagai berikut.

Survei lahan dan penyiapan lahan penanaman di Desa Argosari, Lumajang. Tim pelaksana KKN-PPM berkoordinasi dengan Kepala Desa dan petani lokal yang ditunjuk oleh Kepala Desa sebagai petani yakon. Petani lokal mempersiapkan lahan sejak satu minggu sebelum penanaman yakon dimulai. Lokasi penanaman merupakan lokasi yang telah ditetapkan di wilayah KKN PPM, yaitu Desa Argosari. Penyiapan lahan 30 hari sebelum tanam. Lahan yang telah ditetapkan dibersihkan dari gulma kemudian dicangkul secara manualau dengan menggunakan alat mekanik untuk menggemburkan tanah pada lapisan top soil dan sub soil serta menembalikan kesuburan tanah. Tanah dicangkul kedalaman 20-30 cm. Tanah dibiarkan 1-2 minggu agar gas-gas beracun di dalam tanah menguap dan bibit penyakit/hama tanag mati terkena sinar matahari.

Penyiapan bibit yakon oleh pihak petani yakon Wonosobo di desa Argosari. Bibit yang akan ditanam disemai terlebih dahulu dan dipersiapkan sehingga bibit tersebut siap ditanam. Bibit disiapkan dan disemai selama dua minggu. Pengangkutan bibit ke Desa Argosari dilaksanakan pada tanggal 16 April 2016 bertepatan dengan pembukaan Kegiatan KKN-PPM di Desa Argosari.

Pelatihan mahasiswa dan persiapan perlengkapan Penanaman yacon. Sebelum keberangkatan mahasiswa peserta KKN-PPM dilatih selama dua hari berturut-turut 
mengenai gambaran umum yacon, tata cara budidaya yacon, dan perlengkapan yang dibutuhkan selama kegiatan KKN-PPM berlangsung. Pelatihan dilaksanakan oleh ketua pelaksana KKN-PPM, Dosen Pembimbing Lapangan, dan dibantu oleh tiga orang anggota tim teknisi pendukung. Dalam kegiatan ini mahasiswa berdiskusi dengan kelompok tentang pembagian tugas dan rencana pelaksanaan program KKN-PPM.

Penanaman dan perawatan yacon di Desa Argorasi. Pemberangkatan mahasiswa peserta KKN-PPM dilaksanakan pada tanggal 16 April 2016. Pembukaan kegiatan KKNPPM dilaksanakan di Desa Argosari dan dihadiri oleh Kepala Desa dan petani lokal yang akan bertanam yacon. Setelah kegiatan pembukaan, mahasiswa peserta KKN-PPM memilih dan menanam bibit yacon di lahan bersama petani yacon. DPL bertugas memonitor saat kegiatan berlangsung.

Selanjutnya, perawatan tanaman yacon dilakukan oleh petani lokal. Perawatan yacon ini dilaksanakan secara rutin untuk menjaga dan mengecek perkembangan yacon. Selain petani yacon, mahasiswa peserta KKN-PPM juga bertugas merawat dan mencatat perkembangan yacon. Mahasiswa datang ke Desa Argosari setiap hari Sabtu dan Minggu dimulai sejak tanggal 16 April 2016 sampai dengan 16 Juli 2016. Lahan tanaman yacon di desa Argosari seluas $1300 \mathrm{~m}^{2}$ terbagi menjadi 11 petak, masing-masing terdiri dari 10 bedeng. Contoh data perkembangan pertumbuhan tanaman yacon palah salah satu petak sebagai berikut pada Tabel 1 .

Tabel 2. Data Perkembangan Tanaman

\begin{tabular}{|c|c|c|c|c|c|c|c|c|c|c|c|}
\hline \multirow[t]{2}{*}{ watt } & \multicolumn{11}{|c|}{ 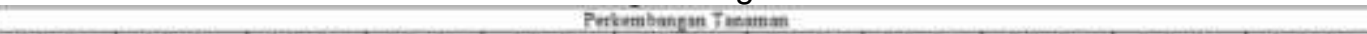 } \\
\hline & PEnin & P-Balin & B. Inxin & Pravilu & Porin & Pinn:ini & PEn Bn & PBoping & PBDiBn & Prenten & Pnimefills \\
\hline MI & 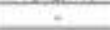 & - & 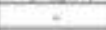 & 4 & - & - & 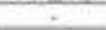 & 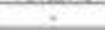 & - & $=$ & - \\
\hline 92 & $=$ & $=$ & $=$ & 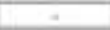 & $=$ & $=$ &. & 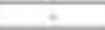 & $=$ & 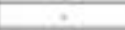 & $=$ \\
\hline MD & 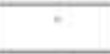 & . & $=$ & s. & - & r & . & 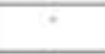 & 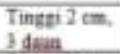 & $\begin{array}{l}\text { Tintsi } 4 \mathrm{~cm}, \\
2 \text { gamp. }\end{array}$ & $\begin{array}{l}\text { Tingad } \mathrm{t} \mathrm{cm} \text {, } \\
2 \mathrm{fana}\end{array}$ \\
\hline Mit &. & - & $\begin{array}{l}\text { Mancul } \\
\text { bascup } \\
\text { Aaun. }\end{array}$ & $\begin{array}{l}\text { Shucd } \\
\text { kunesy } \\
\text { dana tinesi } \\
2 \mathrm{em}, 2 \\
4 \mathrm{man}\end{array}$ & $\begin{array}{l}\text { Mabeut } \\
\text { hincup fans }\end{array}$ & $\begin{array}{l}\text { Mfincut } \\
\text { hunciap danu }\end{array}$ & 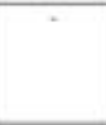 & 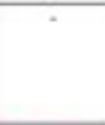 & $\begin{array}{l}\text { Tingti } 3 \mathrm{~cm} \text {, } \\
3 \text { dave }\end{array}$ & $\begin{array}{l}\text { Tingt } 1,5 \\
\mathrm{~cm}, 3 \text { daes }\end{array}$ & $\begin{array}{l}\text { finta } 3 \mathrm{~cm} \text {. } \\
2 \text { faus }\end{array}$ \\
\hline MS & $\begin{array}{l}\text { Mascu! } \\
\text { buscup } \\
\text { daun }\end{array}$ & $\begin{array}{l}\text { Munced } \\
\text { kumasp daum }\end{array}$ & $\begin{array}{l}\text { Tineri 2 } \\
\text { and, } 4 \text { daun }\end{array}$ & $\begin{array}{l}\text { Timeni i } \\
\text { andan S } \\
\text { desa }\end{array}$ & $\begin{array}{l}\text { Tinep Kemin } \\
1 \text { daun }\end{array}$ & $\begin{array}{l}\text { Tinte } 3 \mathrm{~cm}, \\
6 \text { dam }\end{array}$ & $\begin{array}{l}\text { Muncal } \\
\text { kuacup } \\
\text { danas }\end{array}$ & $\begin{array}{l}\text { Stancul } \\
\text { baecup } \\
\text { dwa testi } \\
1 \mathrm{zm}, 1 \\
\text { Aani }\end{array}$ & $\begin{array}{l}\text { Tingtr 4,5 } \\
\text { an, } 5 \text { daun }\end{array}$ & $\begin{array}{l}\text { Tintri } 9 \text { cin } \\
\text { I Saun }\end{array}$ & $\begin{array}{l}\text { Tingat } 4 \mathrm{~cm} \text {, } \\
4 \text { daral }\end{array}$ \\
\hline 916 & $\begin{array}{l}\text { Tinget } 2.5 \\
\mathrm{~cm}-4 \text { taim }\end{array}$ & $\begin{array}{l}\text { Tingei i ch, } \\
2 \text { dem }\end{array}$ & $\begin{array}{l}\text { Tinge } 3,5 \\
\mathrm{~cm}, 8 \text { tann }\end{array}$ & 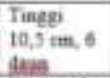 & $\begin{array}{l}\text { Tingsi } \\
2.9 \mathrm{em}, 1 \\
\text { sum }\end{array}$ & $\begin{array}{l}\text { Tingas } 5 \mathrm{~cm} \text {, } \\
6 \text { daw }\end{array}$ & $\begin{array}{l}\text { Tinggi } 1,5 \\
c=2 \text {, waun }\end{array}$ & $\begin{array}{l}\text { Tingei } 2 \\
\mathrm{~cm}, 4 \text { dast }\end{array}$ & 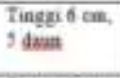 & $\begin{array}{l}\text { Tinge } 7 \mathrm{car} \\
\text { itsan }\end{array}$ & $\begin{array}{l}\text { Tingagi } 5 \mathrm{~cm} \text {, } \\
4 \text { tama }\end{array}$ \\
\hline M7 & $\begin{array}{l}\text { Tants } 5 \\
\mathrm{~cm}, 6 \text { dman }\end{array}$ & $\begin{array}{l}\text { Tineti } 3 \mathrm{am} \text {, } \\
6 \text { dana }\end{array}$ & 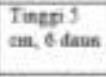 & 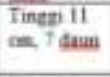 & $\begin{array}{l}\text { Tinesi } \\
4,2 \mathrm{~mm}, 2 \\
\text { gma }\end{array}$ & $\begin{array}{l}\text { Tinte } 5 \text { em. } \\
\text { of daus }\end{array}$ & $\begin{array}{l}\text { Tingpi } 3,3 \\
c=2 \text { daun }\end{array}$ & $\begin{array}{l}\text { Tintzi 2,5 } \\
\text { cme, } 4 \text { dasa }\end{array}$ & $\begin{array}{l}\text { Tints } 8 \mathrm{~cm} \text {, } \\
\text { T dewa }\end{array}$ & $\begin{array}{l}\text { Tinten 7,5 } \\
\text { cme, } 4 \text { dasen }\end{array}$ & $\begin{array}{l}\text { Tinte } 7 \text { am. } \\
6 \text { dans }\end{array}$ \\
\hline MfI & $\begin{array}{l}\text { Tinge ? } \\
\text { em, Thaun }\end{array}$ & $\begin{array}{l}\text { Tines i en: } \\
\text { of dem }\end{array}$ & $\begin{array}{l}\text { Tinges 1,5 } \\
\text { am, } 6 \text { darm }\end{array}$ & $\begin{array}{l}\text { Tings } \\
12 e=1 \\
\text { dase }\end{array}$ & $\begin{array}{l}\text { Tinzes } 6 \mathrm{~cm} \\
4 \text { daun }\end{array}$ & $\begin{array}{l}\text { Tinges } 5 \mathrm{~cm} \text {. } \\
6 \text { daxo }\end{array}$ & $\begin{array}{l}\text { Tinggi } 5,5 \\
\mathrm{~cm}, 5 \text { daun }\end{array}$ & $\begin{array}{l}\text { Tingsi 4,5 } \\
\text { em, } 6 \text { daus }\end{array}$ & $\begin{array}{l}\text { Tinges } 10,3 \\
\operatorname{tm}, 9 \text { gaun }\end{array}$ & $\begin{array}{l}\text { Tangse } 9 \mathrm{em}, \\
4 \text { daun }\end{array}$ & $\begin{array}{l}\text { Tindat i em, } \\
\text { I dave }\end{array}$ \\
\hline $\mathbf{9 9}$ & $\begin{array}{l}\text { Tintsi } 9 \\
\operatorname{sin:} 9 \text { dagh }\end{array}$ & 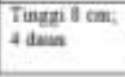 & $\begin{array}{l}\text { Tingti } 10 \\
\text { cm, daue } 4 \\
\text { gisang. }\end{array}$ & $\begin{array}{l}\text { Timen } 15 \\
\cos \text {, daun }\end{array}$ & $\begin{array}{l}\text { Tines I ton, } \\
\text { 9 dasu }\end{array}$ & $\begin{array}{l}\text { Tate } 3 \mathrm{~cm}, \\
6 \mathrm{dang}\end{array}$ & $\begin{array}{l}\text { Tingni } 9 \\
c=3 \text { daus }\end{array}$ & $\begin{array}{l}\text { Tinsti } 6,5 \\
\text { call. } 4 \text { daus }\end{array}$ & $\begin{array}{l}\text { Tinge } \\
17,5=0,9 \\
\text { deas }\end{array}$ & $\begin{array}{l}\text { Texps } 14 \\
\mathrm{~cm}, 9 \text { daves }\end{array}$ & 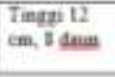 \\
\hline
\end{tabular}

M-Minegu

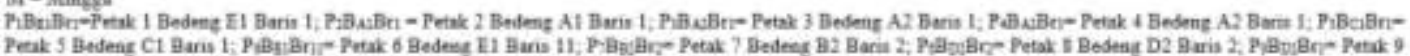

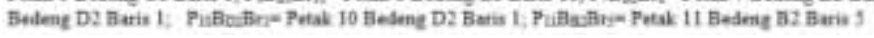

Pada tanggal 28 Mei 2016 tim pelaksana menyerahkan alat pengering daun ke Desa Argosari. Tim pelaksana KKN-PPM memberikan pelatihan penggunaan alat bagi petani yacon. Kegiatan ini dihadiri oleh Kepala Desa dan petani yacon. Adapun tahap pengeringan daun yacon dari tanaman yacon desa Argosari dilaksanakan pada tanggal 19 Oktober 2016, disesuaikan dengan pertumbuhan yacon hingga yacon daun yacon sudah terbentuk cukup banyak.

Kegiatan penutupan KKN-PPM dilaksanakan pada tanggal 16 Juli 2016. Kegiatan penutupan ini merupakan kegiatan penutupan KKN bagi mahasiswa, namun Tim Pelaksana masih tetap melanjutkan program
KKN-PPM hingga pemanenan daun dan pembuatan teh daun yacon.

Pemanenan daun yacon untuk dimanfaatkan sebagai teh yang berfungsi untuk menurunkan glukosa maupun kolesterol darah, dilakukan pada 19 Oktober 2016, setelah daun tumbuh baik berdasarkan pemantauan per periode waktu, seperti yang ditunjukkan pada Gambar 2. 


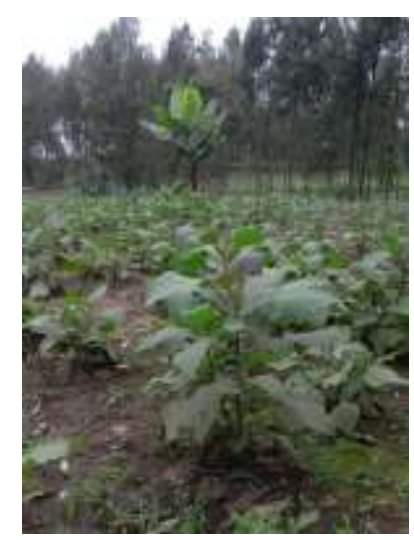

Gambar 2. Tanaman Yacon Ketika Panen Daun

Monitoring kegiatan KKN-PPM yang dilaksanakan oleh DPL untuk memantau perkembangan pelaksanaan rencana kerja program KKN-PPM yang telah dibuat oleh mahasiswa. Selama kegiatan monitoring, DPL berdiskusi dengan mahasiswa mengenai proses kegiatan KKN-PPM dan kendala yang dihadapi beserta solusi terhadap kendala tersebut. Kegiatan monitoring ini dilaksanakan setiap minggu oleh DPL.

Penulisan dan diskusi Progress Report mahasiswa KKN-PPM. Setiap minggu mahasiswa menulis Progress Report KKNPPM dan mendiskusikan hasil kegiatan mereka. Mahasiswa mempresentasikan Progress Report tersebut dengan bimbingan dari DPL.

Monitoring perkembangan tanaman yacon pasca kegiatan KKN. Pasca kegiatan KKNPPM yang dilaksankan oleh mahasiswa FMIPA Unesa, Tim Pelaksana tetap melanjutkan program kegiatan, yaitu memonitor perkembangan tanaman yacon. Petani yacon di Desa Argosari bertugas merawat tanaman yacon termasuk merekam perkembangan yacon tersebut.

Pembuatan teh yacon di Desa Argosari. Kegiatan pembuatan teh yacon dilaksanakan pada Tanggal 19 Oktober 2016 dan diikuti oleh warga Desa Argosari. Kegiatan tersebut diawali dengan pemanenan daun yacon dari lahan penanaman yang dapat dilihat pada Gambar berikut. Daun yang telah dipanen, kemudian dikeringkan menggunakan alat pengering daun untuk pembuatan teh. Suhu yang digunakan untuk pengeringan daun yacon adalah $60^{\circ} \mathrm{C}$ selama 30 menit. Daun yacon kering masih terlihat berwarna hijau dengan bebarapa bagian berwarna kecoklatan. Daun kering tersebut, kemudian digiling dengan menggunakan copper untuk menghasilkan teh daun yacon. Daun yacon yang telah digiling, kemudian diseduh dengan air panas untuk menghasilkan teh yacon. Teh yacon yang dihasilkan memiliki aroma khas dengan warna teh kecoklatan. Peserta pelatihan juga mencoba teh yang dihasilkan. Peserta pelatihan memberikan respon positif terhadap hasil uji coba rasa dan aroma teh yacon, yaitu (1) rasa teh yacon tidak terlalu pahit jika dibandingkan dengan rasa teh hijau pada umumnya dan (2) aroma teh yacon sangat khas dengan sedikit aroma seperti tembakau. Dengan demikian, jika teh yacon dikonsumsi oleh masyarakat luas, mereka tidak akan merasakan teh yang terlalu pahit walaupun tanpa tambahan gula. Selain itu, aroma khas dari teh tersebut akan meningkatkan minat masyarakat terhadap konsumsi teh tersebut.

\section{SIMPULAN DAN SARAN}

Berdasarkan hasil yang telah diperoleh, dapat disimpulkan:

1. Masyarakat di Desa Argosari dapat diberdayakan melalui penanaman Yacon, yang telah berhasil ditanam di Desa Argosari dan daunnya diolah menjadi teh yacon oleh petani di desa tersebut.

2. Mahasiswa KKN telah mampu bersosialisasi dengan masyarakat Desa Argosari melalui program penanaman yacon. Selain itu, mereka menunjukkan sikap tanggung jawab yang dapat dilihat dari perawatan tanaman yacon selama kegiatan KKN.

3. Mahasiswa telah mampu mengembangkan keterampilan mereka, khususnya dalam hal bercocok tanam yacon. Kegiatan yang dilakukan mahasiswa selama KKN meliputi pelatihan penanaman yacon, penanaman bibit, dan perawatan tanam

Saran untuk kegiatan KKN-PPM selanjutnya adalah melatihkan bagaimana membuat produk olahan yang layak konsumsi masyarakat dan pemasaran produk-produk tersebut.

\section{DAFTAR PUSTAKA}

Anonim1. 2014. Experimenting with Yacón. Diakses melalui http://www.narrowpassagepermacultu re.com/experimenting-with-yacon pada tanggal 14 Maret 2015.

Anonim2. 2014. A Winter Treat - Peruvian Ground Apple. Diakses melalui 
http://earthwisegardening.com/?p=81 2pada tanggal 14 Maret 2015.

Lachman J., Fernandez EC., Orsak M. 2003. Yacon [Smallanthus sonchifolius (Poepp. Et Endl.) H. Robinson] Chemical Composition and Use- A review. $P$ lant Soil Environ.,49,(6):283-290.

Douglas JA., Follett JM., Douglas MH., Deo B., Scheffer JJ., Littler RA., Harris MM. 2007. Effect of Environment and Time of Planting on The Production and Quality of Yacon (Smallanthus sonchifolia (Poepp.et Endl.) H.Robinson) Storage Roots. New Zealand Journal of Crop and Horticultural Science Vol 35: 107-116.

Manrique I., Hermann M. and Bernet T. 2004. Yacon- Fact Sheet. ISBN 929060-244-9. Peru: International Potato Center (CIP) Lima.

Pemerintah Kabupaten Jombang. 2015. Diakses melalui www.lumajang.go.id pada tanggal 3 Maret 2015.
Yuanita L., Hidayati S.,Wikandari PR. 2013. Efektivitas Fruktooligosakarida Umbi Yacon [Smallanthus sonchifolia (Poepp.et Endl.) H.Robinson] sebagai Prebiotik dan Sinbiotik: Variasi Lama Penyimpanan dan Perebusan. Laporan Penelitian: Unesa (tidak dipublikasikan)

Yuanita L.,Wikandari PR. 2014.Mekanisme Hipokolesterolemik dan Hipoglikemik Prebiotik FOS-Inulin Umbi Yacon [Smallanthus sonchifolia (Poepp.et Endl.) H.Robinson] pada Variasi Lama Perebusan. Laporan penelitian: Unesa (tidak dipublikasikan)

Yuanita L.,Wikandari PR. 2015. FOS Umbi Yacon [Smallanthus sonchifolia (Poepp.et Endl.) H.Robinson] sebagai Prebiotik dan Sinbiotik untuk Menghambat Pertumbuhan Bakteri Patogen. (sedang dilakukan penelitian) 